\title{
Molecular detection of virulence genes in Staphylococcus aureus associated with bovine mastitis
}

Villanueva-Medina Christhian D. ${ }^{a}$

${ }^{a}$ Swamp University of the Michoacán de Ocampo State, Food genomics, molecular biology laboratory.

\begin{tabular}{|c|c|}
\hline \begin{tabular}{|c|c|} 
Bacterial culture \\
extraction
\end{tabular} & $\begin{array}{l}\text { Abstract. } \\
\text { Biofilm formation is considered a defense } \\
\text { mechanism against environmental, chemical or } \\
\text { biological factors. Some of the main bacteria with } \\
\text { greater capacity for the formation of these } \\
\text { structures are gram positive, in which } \\
\text { Staphylococcus aureus stands out. This bacterium } \\
\text { is implicated in a large number of diseases of a } \\
\text { livestock nature, such as bovine mastitis, in which } \\
\text { the ability to form a biofilm gives the bacteria a } \\
\text { high resistance to chemical and antibiotic } \\
\text { treatments, causing economic losses to increase. } \\
\text { Therefore, the work seeks to identify in a } \\
\text { molecular way the genes that are involved in the } \\
\text { formation of biofilms, and to know if the bacteria } \\
\text { possess one or more of said genes. The bacteria } \\
\text { were isolated in the municipalities of Venustiano } \\
\text { Carranza (AVC) and Marcos Castellanos (AMC), } \\
39 \text { and } 15 \text { respectively, for a total of } 55 \text { samples. } \\
\text { Total DNA was extracted from all samples, its } \\
\text { quality was verified by electrophoresis, to finally } \\
\text { perform the genetic detection using endpoint } \\
\text { PCR. A total of } 10 \text { genes were tested, of which } \\
\text { their presence in bacteria with the ability to form } \\
\text { biofilms was already proven. The ATCC isolate } \\
\text { was used as a positive control. Only the icaD and } \\
\text { icaA genes amplified, for a percentage of } 27 \% \text { and } \\
24 \% \text { respectively for the AMC isolates. In the case }\end{array}$ \\
\hline
\end{tabular}




\section{of $\mathrm{AVC}$, the data was $41 \%$ for icaD and $37 \%$ for icaA. Comparing the data obtained with a work carried out by Toro Castillo in 2018, in which he sought the best biofilm formers with the same group of bacteria, it was found that bacteria with such capacity also had said ica genes, directly relating them to the formation of biofilms.}

\section{Introduction}

Bacterial biofilms are microbial communities made up of an extracellular matrix of polysaccharides, where groups of bacteteria mainly take refuge from environmental factors or antibiotic, increasing their pathogenesis. Such biofilms constitute a serious problem in milk production, causing bovine mastitis, which causes considerable economic losses and decreases the quality of milk. In the present work, we analyzed which genes are involved in the formation of biofilms and if these are related to the isolates that best form said matrix.

\section{References}

Bedolla, Leon, P. de, \& MER. (2008). Pérdidas económicas ocasionadas por la mastitis bovina en la industria lechera. Revista Electronica de Veterinaria, 1-26.

Boles, B. R., Thoende, M., Roth, A. J., \& Horswill, A. R. (2010). Identification of genes involved in polysaccharide- independent Staphylococcus aureus biofilm formation. PLoS ONE, 5(4). https://doi.org/10.1371/journal.pone.0010146

Hamdam Partida, A., González García, S., \& Bustos Martinéz, J. (2015). Identificación de Staphylococcus aureus utilizando como marcadores los genes nucA y femB. Ciencias Clínicas, 37- 
41.

Hassanzadeh, S., Reza Sepideh, M., Afshar, D., Dehbashi, S., \& Mashhadi, R. (2016). A rapid DNA Extraction of Staphylococcus aureus. Iran J Public Heald, 1093-1095.

Pospiech, A., \& Neumann, B. (1995). A versatil quick-prep of genomic DNA from Gram-positive bacteria. Trends in Genetics, 217-218.

Ramesh, A., Padmapriya, B., Chrashekar, A., \& Varadaraj, M. C. (2002). Aplication of convenient DNA extration method and multiplex PCR for the detection of Staphylococcus aureus and Yersinia enterocolitica. Molecular and Cellular Probes, 307-314.

Zendejas Manzo, G. Z., Avalos Flores, H., \& Padilla Soto, M. Y. (2014). Microbioligía general de Staphylococcus aureus: Generalidades, patogenicidad y métodos de identificación. Sahuayo, Michoacán, México. 